ISSN: $2617-6548$

\title{
Application of Membrane Bioreactor in Wastewater Treatment: A Mini Review
}

\author{
Yasmeen Hafiz Zaki ${ }^{1 *}$, Abdurahman Hamid Nour², Hybat Salih Mohamed ${ }^{3}$ \\ ${ }^{1,2,3}$ Faculty of Chemical \& Natural Resources Engineering, Universiti Malaysia Pahang, Lebuhraya Tun Razak, 26300 Gambang, Pahang, \\ Malaysia \\ *Corresponding author: Yasmeen Hafiz Zaki (zakiyasmeen99@gmail.com)
}

\begin{abstract}
Membrane bioreactor (MBR) is credible and promising technology methods for industrial wastewater treatment and recycle it to use in different applications. Today MBR has many domestic and industrial applications and it is popular among the types of conventional treatment methods. The main drawback in the operation of MBR is membrane fouling, that drive to the decrease in permeate flux so need some technique to clean the membrane. In spite of more than a decade of significant advances in improvement of fouling reduction technique, various physical and mechanical methods are still necessary to be improved to limit the membrane fouling problems. In this review, the advantages and disadvantages of membrane bioreactor, fundamental of membrane fouling that is affected by some factors and methods of controlling membrane fouling were discussed.
\end{abstract}

Keywords: MBR, Membrane fouling, Factors of fouling.

DOI: 10.53894 /ijirss.v1i1.5

Funding: This study received no specific financial support.

History: Received: 25 February 2018/Revised: 16 March 2018/Accepted: 29 March 2018/Published: 21 September 2018

Licensed: This work is licensed under a Creative Commons Attribution 4.0 License $(\mathrm{cc})$ EY

Acknowledgement: All authors contributed to the conception and design of the study.

Competing Interests: The authors declare that they have no conflict of interests.

Transparency: The authors confirm that the manuscript is an honest, accurate, and transparent account of the study was reported; that no vital features of the study have been omitted; and that any discrepancies from the study as planned have been explained.

Ethical: This study follows all ethical practices during writing.

\section{Introduction}

Membrane bioreactor (MBR) is a technology that combines membrane filtration with a biological reactor. Recently, membrane based separation has gained much attention over the conventional separation methods for wastewater treatment. Due to the effective design and operation, this method has significantly used in municipal and industrial wastewater treatment [1].The principle behind this technique is the gravity settling, where the treated water can pass through the membrane but the activated sludge remains on the surface of the membrane. Basically, this method is based on the separation of solid-liquid phases. However, this technique is not effective to remove the bacteria and suspended solids [2]. MBR has shown high efficiency of treatment for wastewater compared to other membrane process. Beside biological degradation, this separation method has the ability to treat polluted water from different industrials process, as well as MBR is a better alternative for conventional treatment techniques such as flocculation, sedimentation, filtration and disinfection [1]. MBR has been applied to be highly effective for the treatment of polluted of many types of wastewater to 
produce potable water it's application not just for biological degradation, but also to replacing other conventional treatment such as flocculation, sedimentation, filtration, and disinfection The characterization of MBR over the conventional Techniques due to outstanding treated water quality high biodegradable efficiency, small footprint and reactor requirements, absolute biomass retention and ease of stable operation [3]. MBR has been known to be effective for wastewater treatment that by improvement solid retention time (SRT), permitting excellent biological treatment of organic pollutant, and decrease the hydraulic retention time (HRT) that return for the feature of membrane able to reject the suspended solids to get highly purified water [4]. However, there are many disadvantages when using the MBR technology such as control membrane fouling problems, and the high costs of membrane replacement [5]. During the operation, membrane fouling results in an increase in sludge amount as well as pressure. The pressure differential across the membrane or the driving force required to achieve a given flux, it known as transmembrane pressure (TMP). The TMB is measured by the variation in feed pressure and permeate pressure [6]. The objective of this review was to collect information about the advantages and disadvantages of the MBR and the different factors increase the membrane fouling, and how to control the fouling as well.

\section{The Advantages of Membrane Bioreactor}

\subsection{Small Footprint}

one of the reasons that lead to more reduction of small footprint in the overall for the system is the reactor can operate at a higher mixed liquor suspended solids (MLSS) concentration, that leads to the smaller volume required to treat the same waste $[7,8]$.

\subsection{High Quality Effluent}

The pore size of the membrane is very small (typically $0.1 \mu \mathrm{m}$ for microfiltration), that indicates the effluent suspended solids (SS) content is very low. In modern studies found that the reduction in micro-organisms is more than the conventional methods $[7,9]$.

\subsection{Better Control over Biological Conditions}

Finished the material separation (solid or liquid), all sludge can be retentate to the reactor. This means the age of sludge is independent of HRT. To in order to control the microorganism reaction, it prefers to monitor the HRT and SRT [10].

MBR can be used for ultrafiltration and nanofiltration process. However, for the treatment of wastewater the ultrafiltration is considered more suitable than the nanofiltration. Because, ultrafiltration is low cost process and able to remove the contaminants. The nanofiltration reserve osmosis is a deep separation process which is good for drinking water but it is time consuming and costly to be used for treated water for industrial applications [11]. The others types of the membrane, for instance, nanofiltration and reverse osmosis have a high cost compared ultrafiltration (UF) consider as a method to remove the contaminations from the wastewater $[12,13]$.

\section{The Precept and Mechanisms of Membrane Fouling}

The great issue of membrane separation processes is membrane fouling. Which it consider the main obstacle to applied on MBRs $[14,15]$. Decrease the lifespan of the membrane, when the membrane fouling occurs, due to material deposits and accumulates on the membrane surface or in the membrane pores, that decrease the permeability of the membrane, rise the feed pressure, increase system downtime, reduce productivity, increase membrane maintenance and operation costs due to membrane cleaning [16]. The membrane fouling occurs by the materials that accumulate on the membrane surface. These materials typically consist of suspended particulates (primarily microorganisms and cell wreckage), solutes, and colloids [17]. In other hand the presence of fouling cause the reduction of permeate flux for constant pressure operation. The mixture nature of active microorganisms in mixed liquor suspended solids (MLSS) and suspended solids create membrane fouling that is difficult challenge to control in long-term MBR applications [18]. In the membrane fouling area, a lot of extensive research in order to improve the broad application of the MBR technology in wastewater.

\section{Factors Affecting Membrane Fouling}

Membrane fouling is an especial interaction between the membrane and different components (suspended solids and microorganisms) of the feed wastewater. Using different operating conditions the feed compounds reaction with the membrane and there are very difficult to put professional theory or rules about the component pool on the surface of the membrane. In general, the factors affecting membrane fouling can be grouped into two categories:

\subsection{Membrane Properties}

4.1.1. Material Type

One of the famous impacts on the membrane fouling is material of the membrane. Generally, the membrane material can be divided into ceramic membranes, polymeric membranes, and composite membranes. Ceramic membrane is made from organic material and it is perfect filtration performance that returns to their high chemical resistance, highly hydrophilic which create more fouling resistant, ease of cleaning and the operation is low costs. It used for liquid filtration $[19,20]$. Polymeric membranes are known with the most effective types available. It has an excellent physical and chemical resistance and hydrophobicity. The reason which makes the polymeric membranes resist the foul easily is a fabrication of the pore sizes [21]. To overcome of membrane fouling were plated with a hydrophilic polymer, this is known 
as composite membrane. Thus, the recent research has been focusing on enhancing the membrane material to reduce the membrane fouling [22].

\subsubsection{Characterization of Membrane Surface}

The surface of membrane controllable of the fouling, the surface roughness has the effect on membrane fouling in MBRs [23]. The homogeneous surfaces of the membrane are minimal to being fouled than those with uneven surfaces [24].

\subsubsection{The Role of Membrane Pore Size}

Usually, the pore size of a membrane returned to the size of particles in the effluent feed stream in MBRs which influence the membrane fouling [25]. Mostly, membranes applied in wastewater treatment are wildly divided into two, porous membranes and non-porous membranes. Microfiltration (MF), ultrafiltration (UF), and loose end nanofiltration (NF) membranes, these as known Porous membranes [26, 27]. On the other hand, used Non-porous membranes in the various in diffusivity or solubility between the solvent and the solute in the membranes for separation [27]. Generally, the particle size distribution of the feed stream effected on the structure of the membrane pore, and when the particle size is smaller than the membrane pores the particles permeate into or block the pores [28]. This is attributable to easier for particles to enter the membrane pores and closed it, then the pore blocking [24].

\subsection{Operating Conditions}

Operating parameters such as transmembrane pressure, Solids Retention Time (SRT) and Hydraulic Retention Time (HRT, temperature. High SRTs are not favourite due it increase membrane fouling by accumulation the matters, microorganisms and increasing sludge viscosity [29]. It found that the lower membrane fouling rates at 30 days and 50 days SRTs contrast to 10 days SRT. That means the operating above 50 days indicate to increase fouling [30]. Likewise, the operating at low SRTs (Less than two days) it causes to increase the membrane fouling [31]. That has been attributed to increase the concentration of soluble and suspended solids. Low SRTs causes the reduction in MBR performance and low biomass concentration [32]. Generally as is known the rate of Membrane fouling in MBRs increases when HRT reduced [33]. Moreover, the decrease in HRT direct increases in MLSS concentration and biomass viscosity that predominant factors that affect hydrodynamic conditions of MBR systems [32]. It is reported that operated the MBRs at 14,18 and 20 days increased the concentration and viscosity of sludge thus intense the fouling [34]. One of the influencing factors is temperature. The low temperatures during the process cause the increased of filamentous bacteria which create soluble microbial products, hence more severe for membrane fouling.

In the MBRs have two types of TMP, one is constant TMP with variable penetrate flux and second is constant penetrate flux with variable TMP. It observed that TMP increase the membrane fouling at a constant permeate flux [21]. The TMP They mention that during the experiments were carried out at fixed flux, the TMP keep constant or increasing gradually to causes the fouling. Thus, to decrease the membrane fouling should be constant filtrate flux [35].

\section{Types of Membrane Fouling}

The main phenomena of membrane fouling is accumulation of organic and inorganic particles, colloids and microorganisms on the surface, or closed the pores of membrane. On the other hand the fouling means the adhesion of particles on the surface. Generally, fouling can be classified into two types [6]:

\subsection{External Fouling}

The adsorption or sedimentation of solutes (the component in a solution) on the external membrane surface called External membrane fouling [36, 37]. External fouling prevents the transfer of solutes via blocking the pore entrance or increasing the effective membrane thickness fully and partially [38].

\subsection{Internal Fouling}

Indicates to the adsorption or sedimentation of solute molecules within the pores of membrane [37]. Due to these interactions in pore blocking of the membrane that can drive to irreversible fouling of the membrane [39]. Figure 1 shows the various fouling technique.

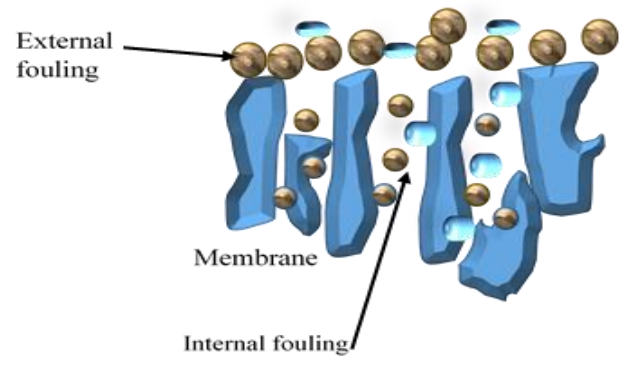

Figure-1.

External and Internal fouling on the membrane. 


\section{Mechanism of Cleaning Ultrafiltration Membranes}

Membrane separation processes use in several industrial processes. Generally, to separate or treatment dairy, biochemical and pharmaceutical industries using ultrafiltration. That used in the heavy process, due to high solid loading [40]. There are some conventional procedures, removed the fouling in the membrane such as soaked in a strong alkaline solution containing detergents/surfactants, washed and re-used. However, use the technique cleaning by expensive chemical causes negative effect on both economy and environmental. Another way to clean ultrafiltration by using the ultrasonic membrane has been widely studied by Kentish and Ashokkumar [41]; Abdurahman, et al. [42]. Used ultrasonic membrane for cleaning the surface of membrane one of the method found a large success. The studies are still advanced and developed every day in this subject.

\section{Fouling Control}

The important point to control the fouling is operation conditions can reduce membrane fouling to some limit. The fouling is created due to some reasons such as some complicated reaction may happen between the particles and the surface of the membrane, and the particles rejected by or adsorbed on the membrane surface. Recently, it should be found some solutions to apply a suitable operation or cleaning strategies to prevent the complicated reaction before it happens. The new solution by Ultrasonic membrane anaerobic system (UMAS) for reduce the fouling and treat a various types of wastewater this reported by Abdurahman, et al. [43]. The control of various fouling technique is not easy in the different types of membrane may require different operating and cleaning strategies [11].

\section{Conclusions}

This review paper gives the technique of MBR advantages and the major problem facing it. Due to use MBR in different types of separate or treatment for industrial wastewater. The MBR fouling cleaning becoming the intense area to develop it. MBR effected by some factors and their interactions have a big role. Nevertheless, used the chemical to clean the membrane which considers expensive and the effect of this chemical on the membrane material. Recently used ultrasonic membrane anaerobic system to reduce the membrane fouling and treat wastewater.

\section{References}

[1] B. Ladewig and M. N. Z. Al-Shaeli, Fundamentals of membrane Bioreactors: Materials, Systems and membrane fouling: Springer, 2016.

[2] Y. Li, T. S. Chung, and S. Kulprathipanja, "Enhanced gas separation performance in polyethersulfone (Pes)-modified zeolite mixed matrix membranes," presented at the 05AIChE: 2005 AIChE Annual Meeting and Fall Showcase, 2005.

[3] S. Judd, The MBR book: Principles and applications of membrane bioreactors for water and wastewater treatment: Elsevier, 2010 .

[4] A. Charfi, M. Aslam, and J. Kim, "Modelling approach to better control biofouling in fluidized bed membrane bioreactor for wastewater treatment," Chemosphere, vol. 191, pp. 136-144, 2018.Available at: https://doi.org/10.1016/j.chemosphere.2017.09.135.

[5] G. Tchobanoglous, D. Stensel, R. Tsuchihashi, F. L. Burton, A. O. Mohammad, G. Bowden, and W. Pfrang, Wastewater engineering: Treatment and resource recovery: Metcalf \& Eddy, Inc, 2014.

[6] B. Ladewig and M. N. Z. Al-Shaeli, Fundamentals of membrane bioreactors: Springer Transactions in Civil and Environmental Engineering, 2017.

[7] H. Thomas, S. Judd, and J. Murrer, "Fouling characteristics of membrane filtration in membrane bioreactors," Membrane Technology, vol. 2000, pp. 10-13, 2000.Available at: https://doi.org/10.1016/s0958-2118(00)88959-4.

[8] G. T. Daigger, B. E. Rittmann, S. Adham, and G. Andreottola, "Are membrane bioreactors ready for widespread application?," Environmental Science \& Technology, vol. 39, pp. 399A-406A, 2005.Available at: https://doi.org/10.1021/es053358+.

[9] N. Cicek, H. Winnen, M. T. Suidan, B. E. Wrenn, V. Urbain, and J. Manem, "Effectiveness of the membrane bioreactor in the biodegradation of high molecular weight compounds," Water Research, vol. 32, pp. 1553-1563, 1998.Available at: https://doi.org/10.1016/s0043-1354(97)00350-3.

[10] E. Trouve, V. Urbain, and J. Manem, "Treatment of municipal wastewater by a membrane bioreactor: Results of a semiindustrial pilot-scale study," Water Science and Technology, vol. 30, p. 151, 1994.Available at: https://doi.org/10.2166/wst.1994.0180.

[11] W. Gao, H. Liang, J. Ma, M. Han, Z.-1. Chen, Z.-s. Han, and G.-b. Li, "Membrane fouling control in ultrafiltration technology for drinking water production: A review," Desalination, vol. 272, pp. 1-8, 2011.Available at: https://doi.org/10.1016/j.desal.2011.01.051.

[12] E. K. Yanful, Appropriate technologies for environmental protection in the developing world: Springer, 2009.

[13] J.-M. Laîné, D. Vial, and P. Moulart, "Status after 10 years of operation-overview of UF technology today," Desalination, vol. 131, pp. 17-25, 2000.Available at: https://doi.org/10.1016/s0011-9164(00)90002-X.

[14] F. Meng, S. R. Chae, A. Drews, M. Kraume, H. S. Shin, and F. Yang, "Recent advances in membrane bioreactors (MBRs): Membrane fouling and membrane material," Water Research, vol. 43, pp. 1489-1512, 2009.

[15] L. Shen, X. Wang, R. Li, H. Yu, H. Hong, H. Lin, J. Chen, and B.-Q. Liao, "Physicochemical correlations between membrane surface hydrophilicity and adhesive fouling in membrane bioreactors," Journal of Colloid and Interface Science, vol. 505, pp. 900-909, 2017.Available at: https://doi.org/10.1016/j.jcis.2017.06.090.

[16] W. Guo, H.-H. Ngo, and J. Li, "A mini-review on membrane fouling," Bioresource Technology, vol. 122, pp. 27-34, 2012.Available at: https://doi.org/10.1016/j.biortech.2012.04.089.

[17] D. Jeison and J. B. van Lier, "Cake formation and consolidation: Main factors governing the applicable flux in anaerobic submerged membrane bioreactors (AnSMBR) treating acidified wastewaters," Separation and Purification Technology, vol. 56, pp. 71-78, 2007.Available at: https://doi.org/10.1016/j.seppur.2007.01.022. 
[18] I.-S. Chang, P. Le Clech, B. Jefferson, and S. Judd, "Membrane fouling in membrane bioreactors for wastewater treatment," Journal of Environmental Engineering, vol. 128, pp. 1018-1029, 2002.

[19] L. Jin, S. L. Ong, and H. Y. Ng, "Comparison of fouling characteristics in different pore-sized submerged ceramic membrane bioreactors," Water Research, vol. 44, pp. 5907-5918, 2010.Available at: https://doi.org/10.1016/j.watres.2010.07.014.

[20] B. Hofs, J. Ogier, D. Vries, E. F. Beerendonk, and E. R. Cornelissen, "Comparison of ceramic and polymeric membrane permeability and fouling using surface water," Separation and Purification Technology, vol. 79, pp. 365-374, 2011.Available at: https://doi.org/10.1016/j.seppur.2011.03.025.

[21] N. S. A. Mutamim, Z. Z. Noor, M. A. A. Hassan, A. Yuniarto, and G. Olsson, "Membrane bioreactor: Applications and limitations in treating high strength industrial wastewater," Chemical Engineering Journal, vol. 225, pp. 109-119, 2013.Available at: https://doi.org/10.1016/j.cej.2013.02.131.

[22] H. Y. Yu, L. Q. Liu, Z. Q. Tang, M. G. Yan, J. S. Gu, and X. W. Wei, "Surface modification of polypropylene microporous membrane to improve its antifouling characteristics in an SMBR: Air plasma treatment," Journal of Membrane Science, vol. 311, pp. 216-224, 2008.Available at: https://doi.org/10.1016/j.memsci.2007.12.016.

[23] H. Guo, Z. Yao, J. Wang, Z. Yang, X. Ma, and C. Y. Tang, "Polydopamine coating on a thin film composite forward osmosis membrane for enhanced mass transport and antifouling performance," Journal of Membrane Science, vol. 551, pp. 234-242, 2018.Available at: https://doi.org/10.1016/j.memsci.2018.01.043.

[24] G. Guglielmi and G. Andreottola, Selection and design of membrane bioreactors in environmental bioengineering. In Environmental Biotechnology. Totowa, NJ: Humana Press, 2010.

[25] F. Galiano, I. Friha, S. A. Deowan, J. Hoinkis, Y. Xiaoyun, D. Johnson, R. Mancuso, N. Hilal, B. Gabriele, and S. Sayadi, "Novel low-fouling membranes from lab to pilot application in textile wastewater treatment," Journal of Colloid and Interface Science, vol. 515, pp. 208-220, 2018.Available at: https://doi.org/10.1016/j.jcis.2018.01.009.

[26] K. Scott, Handbook of industrial membranes: Elsevier, 1995.

[27] S. Shirazi, C.-J. Lin, and D. Chen, "Inorganic fouling of pressure-driven membrane processes-a critical review," Desalination, vol. 250, pp. 236-248, 2010.Available at: https://doi.org/10.1016/j.desal.2009.02.056.

[28] K.-J. Hwang, C.-Y. Liao, and K.-L. Tung, "Effect of membrane pore size on the particle fouling in membrane filtration," Desalination, vol. 234, pp. 16-23, 2008.Available at: https://doi.org/10.1016/j.desal.2007.09.065.

[29] T. Jiang, S. Myngheer, D. J. De Pauw, H. Spanjers, I. Nopens, M. D. Kennedy, G. Amy, and P. A. Vanrolleghem, "Modelling the production and degradation of soluble microbial products (SMP) in membrane bioreactors (MBR)," Water Research, vol. 42, pp. 4955-4964, 2008.Available at: https://doi.org/10.1016/j.watres.2008.09.037.

[30] G. Sabia, M. Ferraris, and A. Spagni, "Model-based analysis of the effect of different operating conditions on fouling mechanisms in a membrane bioreactor," Environmental Science and Pollution Research, vol. 23, pp. 1598-1609, 2016.Available at: https://doi.org/10.1007/s11356-015-5372-z.

[31] P. Le-Clech, V. Chen, and T. A. Fane, "Fouling in membrane bioreactors used in wastewater treatment," Journal of Membrane Science, vol. 284, pp. 17-53, 2006.Available at: https://doi.org/10.1016/j.memsci.2006.08.019.

[32] F. Meng and F. Yang, "Fouling mechanisms of deflocculated sludge, normal sludge, and bulking sludge in membrane bioreactor," Journal of Membrane Science, vol. 305, pp. 48-56, 2007.Available at: https://doi.org/10.1016/j.memsci.2007.07.038.

[33] S. R. P. Shariati, B. Bonakdarpour, N. Zare, and F. Z. Ashtiani, "The effect of hydraulic retention time on the performance and fouling characteristics of membrane sequencing batch reactors used for the treatment of synthetic petroleum refinery wastewater," Bioresource Technology, vol. 102, pp. 7692-7699, 2011.Available at: https://doi.org/10.1016/j.biortech.2011.05.065.

[34] S. Judd, "The status of membrane bioreactor technology," Trends in Biotechnology, vol. 26, pp. 109-116, 2008.

[35] S. Robinson, S. Z. Abdullah, P. Bérubé, and P. Le-Clech, "Ageing of membranes for water treatment: Linking changes to performance," Journal of Membrane Science, vol. 503, pp. 177-187, 2016.Available at: https://doi.org/10.1016/j.memsci.2015.12.033.

[36] K. Hu and J. Dickson, Membrane processing for dairy ingredient separation: John Wiley \& Sons, 2015.

[37] K. Nath, Membrane separation processes: PHI Learning Pvt. Ltd, 2017.

[38] S. S. Manickam and J. R. McCutcheon, "Understanding mass transfer through asymmetric membranes during forward osmosis: A historical perspective and critical review on measuring structural parameter with semi-empirical models and characterization approaches," Desalination, vol. 421, pp. 110-126, 2017.Available at: https://doi.org/10.1016/j.desal.2016.12.016.

[39] R. Ghosh, Protein bioseparation using ultrafiltration: Theory, applications and new developments: World Scientific, 2003.

[40] S. Muthukumaran, S. E. Kentish, G. W. Stevens, and M. Ashokkumar, "Application of ultrasound in membrane separation processes: A review," Reviews in Chemical Engineering, vol. 22, pp. 155-194, 2006.Available at: https://doi.org/10.1515/revce.2006.22.3.155.

[41] S. Kentish and M. Ashokkumar, Ultrasonic membrane processing. In Ultrasound Technologies for Food and Bioprocessing. New York: Springer, 2011.

[42] N. Abdurahman, Y. Rosli, N. Azhari, and H. A. Bari, "The potential of ultrasonic membrane anaerobic systems in treating slaughterhouse wastewater," Journal of Water Reuse and Desalination, vol. 5, pp. 293-300, 2015.Available at: https://doi.org/10.2166/wrd.2015.107.

[43] N. H. Abdurahman, Y. M. Rosli, and N. H. Azhari, "The potential of ultrasonic membrane anaerobic system (UMAS) in treating slaughterhouse wastewater," ARPN: Journal of Engineering and Applied Sciences, vol. 11, pp. 2653-2659, 2016. 